\title{
Systemiske steroider til førskolebarn med symptomer fra nedre luftveier
}

\author{
Episoder med akutt luftveisobstruksjon er svært vanlig hos førskolebarn. Behandling med systemiske stero- \\ ider kan være aktuelt for noen, men i de fleste tilfeller vil slik behandling ikke være indisert. Ved feil bruk vil \\ behandlingen ikke ha effekt og barna kan påføres uønskede bivirkninger. Bruken av systemiske steroider ved \\ akutt luftveisobstruksjon er økende, og vi ønsker å rette oppmerksomheten mot slik feilbehandling.
}

Virale luftveisinfeksjoner er vanligste årsak til akutt pustebesvær hos førskolebarn. Hevelse i slimhinner og økt sekretdanning gjør luftveiene trangere og fører til varierende grad av obstruksjon. Obstruksjon i larynx og ekstratorakale del av nedre luftveier gir inspiratoriske symptomer (stridor). Hos førskolebarn ses dette vanligvis ved akutt laryngitt. Obstruksjon i intratorakale deler av nedre luftveier gir ekspiratoriske symptomer med forlenget ekspirium og ekspiratoriske pipelyder. I denne aldersgruppen er ekspiratorisk obstruksjon vanlig både ved virale luftveisinfeksjoner og ved akutt forverring av astma.

Behandling med systemiske steroider kan være aktuelt hos noen barn med inspiratorisk og ekspiratorisk luftveisobstruksjon. Peroral behandling med systemiske steroider var tidligere tilgjengelig kun ved bruk av tabletter, men i de senere år har slik behandling vært enklere å administrere til førskolebarn i form av vannløselige tabletter med betametason (Betapred), som tas inn på registreringsfritak.

De siste årene har det vært en betydelig økning i bruken av betametasontabletterantall døgndoser solgt fra grossist til apotek har økt med ca. $180 \%$ og antallet barn $i$ aldersgruppen $0-5$ år som har fått resept på tabletter med betametason er tredoblet fra 2009 til 2015 (Øystein Karlstad, Reseptregisteret, Folkehelseinstituttet, personlig meddelelse). Vi vil derfor kommentere indikasjoner for og bivirkninger ved bruk av systemiske steroider til førskolebarn med luftveisobstruksjon.

\section{Akutt laryngitt}

Enkeltstudier og metaanalyser har vist at systemiske steroider har god effekt på luftveisobstruksjon ved laryngitt - symptomene blir redusert, det blir mindre behov for innleggelse, varigheten av sykehusopphold blir kortere og det blir mindre behov for intubasjon $(1,2)$. Både deksametason og betametason kan benyttes, og det vil ofte være tilstrekkelig med én dose (1).

Bare ca. $1-5 \%$ av alle barn med laryngitt innlegges i sykehus, og de aller fleste barn med akutt laryngitt har et mildt forløp (1). Vi mener derfor at systemiske steroider bare bør vurderes ved moderat eller alvorlig luftveisobstruksjon, primært for å redusere behovet for innleggelse i sykehus. De fleste barn har kun ett eller få tilfeller med akutt laryngitt. Ved residiverende laryngitter kan det være aktuelt at barnet utredes for bakenforliggende årsaker, men foreldre bør ikke utstyres med systemiske steroider til hjemmebruk.

\section{Akutt bronkopulmonal obstruksjon}

Om lag 30-50\% av alle barn vil ha én eller flere episoder med ekspiratorisk luftveisobstruksjon i førskolealderen, spesielt i de første tre leveårene (3). Obstruksjonen er vanligvis forårsaket av sekret og ødem

\section{«Foreldre bør ikke utstyres med syste- miske steroider til hjemmebruk»}

i slimhinnene i forbindelse med virale infeksjoner. I første leveår vil dette ofte bli diagnostisert som bronkiolitt, men også senere ses luftveisobstruksjon i forbindelse med virale infeksjoner, ofte i avtagende grad i løpet av de første leveårene (3).

Hos disse barna vil inflammasjonen i stor grad være preget av nøytrofile granulocytter, og steroider har da mindre effekt. Systemiske steroider har ikke effekt ved bronkiolitt (4), og de fleste studier viser at de heller ikke har effekt ved virusutløste obstruktive episoder hos eldre barn som ikke har astma (5).

Astma kan hos noen barn debutere de første leveårene. Sammenlignet med gruppen med virusutløst bronkopulmonal obstruksjon vil barn med astma oftere debutere med luftveisobstruksjon noe senere (sjelden i første leveår) og ha obstruktive symptomer også mellom luftveisinfeksjonene. Tegn til atopi hos barnet, med allergisk sensibilisering, matallergi, atopisk eksem eller atopi hos nære familiemedlemmer øker også sannsynligheten for astma $(3,6)$.

Hos barn med atopi og astma (atopisk astma) foreligger oftere en kronisk inflammasjon med eosinofile granulocytter. Hos disse barna vil systemiske steroider oftere ha effekt, og de vil kunne være en viktig del av behandlingen av betydelige obstruktive episoder, slik det er hos eldre barn med akutt astma (5).

Det kan ofte være vanskelig å avgjøre om akutt luftveisobstruksjon hos et barn er et uttrykk for astma eller kun virusutløst obstruktivitet, noe som kan gjøre valg av behandlingsstrategi vanskelig $(3,6)$. Hos de fleste som ikke trenger innleggelse i sykehus, vil likevel symptomene være så milde at det ikke vil være indikasjon for behandling med systemiske steroider.

I en nyere oversiktsartikkel ble det konkludert med at systemiske steroider bare bør vurderes hos yngre barn som er innlagt i sykehus og der det er klare holdepunkter for at barnet har atopisk astma (7). Ved systematisk gjennomgang av studier er da også konklusjonen at effekten av systemiske steroider hos førskolebarn med obstruktive episoder utenfor sykehus er lite dokumentert og sannsynligvis sterkt begrenset $(5,6,8)$.

Dersom disse anbefalingene blir fulgt, vil sannsynligvis betydelig færre barn med luftveisobstruksjon i Norge bli behandlet med systemiske steroider.

\section{Bivirkninger av systemiske steroider} Mulige effekter av systemiske steroider må veies opp mot mulige bivirkninger (9). Hos de fleste førskolebarn vil en kort kur ikke medføre klinisk påvirkning av binyrene (10), men i en nyere oversiktsartikkel ble det konkludert med at andre akutte bivirkninger er vanlige (11). Brekninger, atferdsendring eller søvnforstyrrelser kan ses hos ca. $5 \%$ av barn og unge, men mest alvorlig er økt infeksjonstendens, som er rapport hos ca. $1 \%$ få uker etter steroidbehandling (11).

Noen studier har vist at gjentatte behandlinger over tid vil kunne ha effekt på benmineraliseringen og nedsette responsen på adrenokortikotropt hormon (ACTH) (12, 13), mens i andre studier er det ikke påvist slike effekter $(10,14)$.

$\mathrm{Vi}$ er kjent med at foreldre til barn med gjentatte obstruktive episoder utstyres med betametason slik at de kan starte behandling hjemme ved nye episoder med laryngitt eller luftveisobstruksjon. Det er ikke vist at slik hjemmebehandling forebygger innleggelser, tvert imot viste en studie at det heller førte til flere $(15,16)$. Vurdert i forhold til mulige bivirkninger og at det sannsynligvis bare er et fătall av disse barna der behandlingen har effekt, anbefaler vi ikke at for- 
eldre til barn med de beskrevne tilstandene utstyres med perorale steroider for administrering hjemme.

\section{Konklusjon}

Det ser ut til å ha vært en stor økning i bruken av systemiske steroider hos førskolebarn i de senere år. Perorale systemiske steroider kan være effektive hos barn med alvorlig

\section{«Mulige effekter av} systemiske steroider må veies opp mot mulige bivirkninger»

akutt laryngitt og hos barn med betydelig ekspiratorisk luftveisobstruksjon der sannsynligheten for atopisk astma er stor.

Hos barn med mildere symptomer, og spesielt der mistanken om astma er liten, bør systemiske steroider ikke brukes. Bivirkninger er relativt vanlig, og ved gjentatte behandlinger er det muligheter for systemiske bivirkninger.

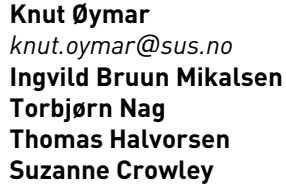

Knut Øymar (f. 1959) er dr.med., spesialist i barnesykdommer, overlege ved Barne- og ungdomsklinikken, Stavanger universitetssjukehus og professor ved Klinisk institutt 2, Universitetet i Bergen.

Forfatter har fylt ut ICMJE-skjemaet og oppgir ingen interessekonflikter.
Ingvild Bruun Mikalsen (f. 1970) er ph.d., spesialist i barnesykdommer, overlege ved Barneog ungdomsklinikken, Stavanger universitetssjukehus og førsteamanuensis ved Klinisk institutt 2, Universitetet i Bergen.

Forfatter har fylt ut ICMJE-skjemaet og oppgir ingen interessekonflikter.

Torbjørn Nag (f. 1978) er spesialist i barnesykdommer og overlege ved Klinikk for kvinner, barn og ungdom, Ålesund sjukehus.

Forfatter har fylt ut ICMJE-skjemaet og oppgir ingen interessekonflikter.

Thomas Halvorsen (f. 1959) er dr.med., spesialist i barnesykdommer, overlege ved Barneog ungdomsklinikken, Haukeland universitetssykehus og professor ved Klinisk institutt 2 . Universitetet i Bergen.

Forfatter har fylt ut ICMJE-skjemaet og oppgir ingen interessekonflikter.

Suzanne Crowley (f. 1956) er dr.med. og spesialist i pediatrisk pulmonologi fra England. Hun er overlege og leder for Den norske legeforenings barnelungeinteressegruppe.

Forfatter har fylt ut ICMJE-skjemaet og oppgir ingen interessekonflikter.

\section{Litteratur}

1. Bjornson $\mathrm{CL}$, Johnson DW. Croup in children. CMAJ 2013; 185: 1317-23.

2. Russell KF, Liang Y, O'Gorman K et al. Glucocorticoids for croup. Cochrane Database Syst Rev 2011 1. CD001955

3. Ducharme FM, Tse SM, Chauhan B. Diagnosis, management, and prognosis of preschool wheeze. Lancet 2014; 383: 1593-604.

4. Fernandes RM, Bialy LM, Vandermeer B et al. Glucocorticoids for acute viral bronchiolitis in infants and young children. Cochrane Database Syst Rev 2013; 6: CD004878.

5. Deshpande DR, Martinez FD. The dilemma of sys temic steroids in preschool children with recurrent wheezing exacerbations. Pediatr Pulmonol 2016; 51: 775-7.

6. Brand PL, Caudri D, Eber E et al. Classification and pharmacological treatment of preschool wheezing: changes since 2008. Eur Respir J 2014: 43: $1172-7$

7. de Benedictis FM, Attanasi M. Asthma in childhood. Eur Respir Rev 2016: 25: 41 -7.

8. Castro-Rodriguez JA, Beckhaus AA, Forno E. Efficacy of oral corticosteroids in the treatment of acute wheezing episodes in asthmatic preschoolers: Systematic review with meta-analysis. Pediatr Pulmonol 2016: 51: 868-76.

9. Beigelman A, Durrani S, Guilbert TW. Should a Preschool Child with Acute Episodic Wheeze be Treated with Oral Corticosteroids? A Pro/Con Debate. J Allergy Clin Immunol Pract 2016; 4 : 27-35.

10. Ducharme FM, Chabot G, Polychronakos C et al. Safety profile of frequent short courses of oral glucocorticoids in acute pediatric asthma: impact on bone metabolism, bone density, and adrenal function Pediatrics 2003. 111. 376-83.

11. Aljebab F, Choonara I, Conroy S. Systematic review of the toxicity of short-course oral corticosteroids in children. Arch Dis Child 2016; 101: 365-70.

12. Guilbert TW, Morgan WJ, Krawiec M et al. The Prevention of Early Asthma in Kids study: design rationale and methods for the Childhood Asthma Research and Education network. Control Clin Trials 2004; 25: 286-310.

13. Kelly HW, Van Natta ML, Covar RA et al. Effect of long-term corticosteroid use on bone mineral density in children: a prospective longitudinal assessment in the childhood Asthma Management Program (CAMP) study. Pediatrics 2008; 122: e53-61.

14. Dolan LM, Kesarwala HH, Holroyde JC et al. Shortterm, high-dose, systemic steroids in children with asthma: the effect on the hypothalamic-pituitaryadrenal axis. J Allergy Clin Immunol 1987; 80: 81-7.

15. Grant CC, Duggan AK, DeAngelis C. Independent parental administration of prednisone in acute asthma: a double-blind, placebo-controlled, crossover study. Pediatrics 1995; 96: 224-9.

16. Oommen A, Lambert PC, Grigg J. Efficacy of a short course of parent-initiated oral prednisolone for viral wheeze in children aged $1-5$ years: randomised controlled trial. Lancet 2003; 362: 1433-8.

Mottatt 14.3. 2017, første revisjon innsendt 30.3. 2017, godkjent 5.4. 2017. Redaktør: Ketil Slagstad.

Publisert først på nett. 